\title{
The gene expression and protein profiles of ADAMTS and TIMP in human chondrosarcoma cell lines induced by insulin: The potential mechanisms for skeletal and articular abnormalities in diabetes
}

\author{
Sumeyya Akyol 1,2, Zehra Karagoz ${ }^{3}$, Nuran Dingil Inan ${ }^{4}$, Ilknur Butun ${ }^{5}$, Ismail Benli ${ }^{5}$, Kadir Demircan²,
} Muhammet Ramazan Yigitoglu ${ }^{6}$, Omer Akyol ${ }^{7,8}$, Semsettin Sahin ${ }^{5}$, Huseyin Ozyurt ${ }^{5}$

\begin{abstract}
Background: The delay in wound healing, decrease in the long bones resilience to fracture, and delay in fracture healing are among common complications diabetes mellitus (DM) patients, and they still remain as challenging issues to be solved. The mechanism has not been fully understood yet, but high sugar and/or insulin deficiency or unresponsiveness to insulin in blood are potential causes to blame. Extracellular matrix degradation/remodeling is one of the important mechanisms whereby cell differentiation, bone remodeling and wound repair can be regulated. A disintegrin and metalloproteinase with a thrombospondin type 1 motif (ADAMTS) proteins play important roles in cartilage/bone metabolism. This study aimed to determine whether ADAMTS/Tissue inhibitors of metalloproteinases (TIMP) proteins were affected by insulin application in OUMS-27 (chondrosarcoma) cells.

Material and Methods: OUMS-27 cells were induced by $10 \mu \mathrm{g} / \mathrm{mL}$ insulin for 1, 3, 7, and 11 days. Cells were harvested, mRNA and protein extractions were performed. Total mRNA and cDNA levels were measured by qRT-PCR and protein levels were detected by WB.

Results: ADAMTS1,5, and 7 levels were significantly decreased, while TIMP-3 levels were detected increased (mRNA/protein concentrations).

Conclusion: Pathologies and disturbances of cartilage/bone metabolism, delayed fracture healing in particular, in patients with DM may result from insulin deficiency. ADAMTS genes that play a role in healing process are increased during insulin deficiency, which consequently interrupts healing process by causing cartilage extracellular matrix (ECM) degradation.
\end{abstract}

Keywords: OUMS-27, chondrosarcoma, diabetes mellitus, insulin, ADAMTS proteins

\section{INTRODUCTION}

Glucose is an essential nutrient for metabolism and structural needs for the growth centers of the hyaline cartilage and the bone growth center. When chondrocytes are left in an anaerobic environment, it does not only use glucose as a primary substrate for the production of ATP $(1,2)$, but it is also the source of glucosamine sulfate which is important for the development, protection, reparation and remodeling of the cartilage. Wound healing, bone resilience, healing of fractured bones and in procedures done before tooth implant surgery to change the bone structure are abnormal in patients with type-2 diabetes mellitus (DM).

\footnotetext{
Beaumont Health System-Research Institute, Royal Oak, MI, USA.

2 Department of Medical Biology, Faculty of Medicine, Turgut Ozal University, Ankara, Turkey

3 Ankara University Biotechnology Institute, Ankara, Turkey

4 Biochemist, 7675 Oaks Lane, Beaumont, TX, USA

5 Department of Medical Biochemistry, Faculty of Medicine, Gaziosmanpasa University, Tokat, Turkey

6 Department of Medical Biochemistry, Faculty of Medicine, Turgut Ozal University, Ankara, Turkey

Michigan Math and Science Academy, Warren, MI, USA

8 Department of Medical Biochemistry, Faculty of Medicine, Hacettepe University, Ankara, Turkey
}

\author{
Correspondence: Sumeyya Akyol \\ Beaumont Health System-Research Institute, Royal Oak, MI, USA \\ Department of Medical Biology, Faculty of Medicine, Turgut Ozal University, Ankara, \\ Turkey \\ E-mail: sumeyyaak@gmail.com
}

Received: 17 Jul 2019, Accepted: 3 Oct 2019

(C) 2020 by the authors; licensee Modestum Ltd., UK. This article is an open access article distributed under the terms and conditions of the Creative Commons Attribution License (http://creativecommons.org/licenses/by/4.0/). 
Recent studies have demonstrated that insulin stimulates bone cells to produce an endocrine hormone that increases the efficiency of glucose metabolism (3). Maxillary sinus graft application is a commonly used dental process to increase bone volume before the insertion of dental implants (4-6). This technique is claimed to be contradictory when used for tooth implants in patients with uncontrolled DM (7). In animal model studies, it is found that DM decreases the bone formation, results in osteopenia and delayed fracture healing (8). In studies examining the impact of DM on bone formation, it is seen that DM delays the fracture healing in experimental fractures of the tibia or femur and that insulin replacement reversed this effect (9). In an experiment conducted on rabbits, whose pancreatic $\beta$-cells were damaged by Alloxan which finally causes type-1 DM, the researchers found decreased levels of newly formed bone mass with blood vessels, as well as the number of osteoblasts, collagen and serum-osteocalcin (10). The treatment of insulin has increased the osteogenesis in the extended maxillary spaces of diabetic rabbits. Thus, decreased bone formation in diabetes models in animals can be prevented via insulin therapy.

Fractures are a significant health issue for patients with both type-1 and -2 DM (11). During the healing process of fractures, when hematoma occurs due to the rupture of blood vessels, progenitor cells come to the damaged area and proliferate to differentiate into osteoblasts and chondrocytes. Chondrocytes produce a cartilage, which forms a soft cartilaginous callus, then turns into calcified form, and finally takes the damaged area under protection. While osteoclasts, turned into apoptosis, are taken away from the environment of mineralized cartilage by chondrocytes, osteoblasts start the endochondral bone formation. Another major problem in type-1 DM is the decrease in bone mineral density and bone formation, which results in osteopenia $(12,13)$. Case-controls and clinical studies of patients with DM also showed prolonged healing of wounds and fractures compared to healthy cases $(14,15)$. Although most of the studies are focused on the bone, the deterioration of cartilage production, which is one of the stages of fracture healing in diabetics, is one of the subjects that need to be investigated. Chondrocyte differentiation and proliferation, which normally occur during fracture healing, have considerably declined in patients with DM $(16,17)$.

Matrix metalloproteinases are capable of digesting extracellular matrix (ECM) macromolecules and non-ECM molecules including receptors, cytokines, chemokines, growth factors, all of which are determinants of the tissue microenvironment. They are present in both acute and chronic wounds. Together with their inhibitors, they play a pivotal role in regulating ECM degradation and deposition (18). It has been proven that a disintegrin and metalloproteinase with a thrombospondin type 1 motif (ADAMTS) proteins, which are members of the metzincins superfamily of zinc-based proteinases, play important roles during growth-development, progression of joint diseases and the metabolism of the cartilage ECM (19). Although the roles of ADAMTS of the chondrocyte growth, differentiation and maturation on the epiphyseal plate are known, their roles in endochondral ossification are not fully proven (20). Researchers have shown the ADAMTS9 mRNA expression during the chondrogenesis of insulin-induced ATDC5 cells. ADAMTS9 is expressed in these chondrocytes and together with the proliferation of chondrocytes and matrix degradation; they help to contribute to its hypertrophy and endochondral ossification process (21). After in vitro induction of chondrogenesis by insulin in ATDC5 cells, the ADAMTS9 expression increased by having/reaching two peaks within 8th-14th days and later within 28th-35th days.

Recent studies of joint diseases in mice lacking metalloproteinase have shown that these proteases have important roles in bone biology and pathology (22). It is not yet understood from which molecular mechanisms these observed phenotypes are disclosed/revealed. As each metalloproteinase cuts its own substrate at a certain point, multiple biological processes arise. Also if we take into account the argument that metalloproteinases serve as communicator molecules between certain bone cells, it shows the necessity to research the subject further to reveal different aspects. Although it is known that ADAMTS 4 and 5 within the matrix metalloprotease are major aggrecanases in the human cartilage, it is not clearly known how these zymogen (inactive) enzyme forms become active and how these activities are managed in vivo. As DM affects the cartilage formation and resorption, it has a negative effect on fracture healing. Although the issue is clinically known, the molecular mechanism is not yet fully understood. How insulin affects the cartilage formation and resorption, which is one of the important stages of fracture healing in in vitro and in vivo conditions, remains as an original subject to study for years to come. The aim of this study is to investigate the quantity and behavioral changes of ADAMTS proteins, which are thought to be related to production and degradation of cartilage synthesized by chondrocytes, during an insulin implementation to the OUMS-27 chondrosarcoma cells. For this purpose, the ECM formation, cartilage production and ADAMTS1, 4, 5, 7, 15 and 18, which have been thought to play an important role in bone formation, and Tissue inhibitors of metalloproteinases (TIMP)-3 and 4, which are inhibitors of the functions of these enzyme, were investigated in terms of mRNA and protein product levels. 
Table 1: Primer design for ADAMTS genes and their detailed information. TM values given by manufacturer and the one calculated in experiments with gradient PCR were also presented in the table.

\begin{tabular}{|c|c|c|c|c|c|}
\hline No & Primer & Primer design & $\begin{array}{l}\text { Product } \\
\text { length }\end{array}$ & $\begin{array}{l}\text { Offered } \\
\text { TM }\end{array}$ & $\begin{array}{c}\text { Calculated } \\
\text { Gradient TM }\end{array}$ \\
\hline \multirow{2}{*}{1} & ADAMTS 1 (453885) & Forward GGACAGGTGCAAGCTCATCTG & \multirow{2}{*}{$72 \mathrm{bp}$} & $66^{\circ} \mathrm{C}$ & \multirow{2}{*}{$57^{\circ} \mathrm{C}$} \\
\hline & ADAMTS 1 (453886) & Reverse TCTACAACCTTGGGCTGCAAA & & $62^{\circ} \mathrm{C}$ & \\
\hline \multirow{2}{*}{2} & ADAMTS 4 (453887) & Forward AGGCACTGGGCTACTACTAT & \multirow{2}{*}{$241 \mathrm{bp}$} & $60^{\circ} \mathrm{C}$ & \multirow{2}{*}{$57^{\circ} \mathrm{C}$} \\
\hline & ADAMTS 4 (453887) & Reverse GGGATAGTGACCACATTGTT & & $58^{\circ} \mathrm{C}$ & \\
\hline \multirow{2}{*}{3} & ADAMTS 5 (453889) & Forward TATGACAAGTGCGGAGTATG & \multirow{2}{*}{$182 \mathrm{bp}$} & $58^{\circ} \mathrm{C}$ & \multirow{2}{*}{$57^{\circ} \mathrm{C}$} \\
\hline & ADAMTS 5 (453890) & Reverse AGGGACTTGTCTGCATGGTG & & $62^{\circ} \mathrm{C}$ & \\
\hline \multirow{2}{*}{4} & ADAMTS 7 (524453) & Forward CATTGGGAACCCCATCCACA & \multirow{2}{*}{$110 \mathrm{bp}$} & $62^{\circ} \mathrm{C}$ & \multirow{2}{*}{$57^{\circ} \mathrm{C}$} \\
\hline & ADAMTS 7 (524454) & Reverse TGCAGAAGCTCTTCAGGGTG & & $62{ }^{\circ} \mathrm{C}$ & \\
\hline \multirow{2}{*}{5} & ADAMTS 15 (453895) & Forward GTGGGGGAGACAATAAGAGC & \multirow{2}{*}{$183 \mathrm{bp}$} & $62^{\circ} \mathrm{C}$ & \multirow{2}{*}{$57^{\circ} \mathrm{C}$} \\
\hline & ADAMTS 15 (453896) & Reverse GGTACTTGCCTTGGCTGTTC & & $62{ }^{\circ} \mathrm{C}$ & \\
\hline \multirow{2}{*}{6} & ADAMTS 18 (454803) & Forward GCCAGTAACTGAGCCCAAAA & \multirow{2}{*}{$66 \mathrm{bp}$} & $60^{\circ} \mathrm{C}$ & \multirow{2}{*}{$57^{\circ} \mathrm{C}$} \\
\hline & ADAMTS 18 (454804) & Reverse CATTCACCTGGCATCCAGTA & & $60^{\circ} \mathrm{C}$ & \\
\hline \multirow{2}{*}{7} & hTIMP-3 (486355) & Forward GCTGGAGGTCAACAAGTACCA & \multirow{2}{*}{$72 \mathrm{bp}$} & $60^{\circ} \mathrm{C}$ & \multirow{2}{*}{$57^{\circ} \mathrm{C}$} \\
\hline & hTIMP-3 (486356) & Reverse CACAGCCCCGTGTACATCT & & $63^{\circ} \mathrm{C}$ & \\
\hline \multirow{2}{*}{8} & Human GAPDH (544445) & Forward CCTGCACCACCAACTGCTTA & \multirow{2}{*}{$108 \mathrm{bp}$} & $62^{\circ} \mathrm{C}$ & \multirow{2}{*}{$57^{\circ} \mathrm{C}$} \\
\hline & Human GAPDH (524446) & Reverse TCTTCTGGGTGGCAGTGATG & & $62{ }^{\circ} \mathrm{C}$ & \\
\hline
\end{tabular}

\section{MATERIALS AND METHODS}

Cell Culture: OUMS-27 chondrosarcoma cells were kindly provided by Dr. T. Kunisada (Okayama University Graduate School of Medicine and Dentistry, Okayama, Japan). OUMS-27 cells were cultured in DMEM containing 10\% BSA and penicillin/streptomycin at $37^{\circ} \mathrm{C}$ in a humidified atmosphere of $5 \% \mathrm{CO}_{2}$. The cells were sub-cultured using trypsin-EDTA at every 7-10 days. The medium was changed every-other-day with either control media or control media supplemented with $10 \mu \mathrm{g} / \mathrm{mL}$ insulin for 11 days.

Four groups of cells (two of each group, one for qRT-PCR and one for Western blot (WB) analysis) were subjected to insulin: For day-1 (D1) experiment, $2 \times 10^{5}$ cells, for day-3 (D3) experiment $1 \times 10^{5}$ cells, for day-7 (D7) experiment $5 \times 10^{4}$ cells, and for day-11 (D11) experiment $3 \times 10^{4}$ cells were plated in 20-mm dishes and exposed to the same concentration of insulin on the days indicated. Insulin powder was dissolved within $0.01 \mathrm{~N} \mathrm{HCl}$. The stock solution had $2 \mathrm{mg} / \mathrm{mL}$ insulin in $0.01 \mathrm{~N} \mathrm{HCl}$, and working solution had $10 \mu \mathrm{g} / \mathrm{mL}$ in medium. Cells were incubated with insulin in medium for one, three, seven, and eleven days. Cells were plated in five dishes for each condition. After the experiment, cells were harvested, and total RNA/protein isolations were performed.

RNA isolation and qRT-PCR: Total RNA was extracted with TRIzol (Invitrogen, Carlsbad, CA) according to the manufacturer's instructions. Two-micrograms of RNA were reverse transcribed with RevertAid M-MuLV Reverse Transcriptase and random hexamers (Thermo Scientific, Waltham, MA) with random primers (Table 1). Human GAPDH was amplified as a control for the PCR. Samples lacking reverse transcriptase were amplified as a control for genomic DNA contamination. RNase-free water (Qiagen $\mathrm{GmbH}$, Germany) was used to elute total RNA. Ultraviolet-visible spectrophotometry was used to quantify and determine the purity of samples (required a 260/280 ratio of 2.0 and a 260/230 ratio of 1.7 for adequate purity).

Quantitative real-time (qRT)-PCR was performed on cDNA samples (Qiagen-Rotor-Gene Q-RT-PCR) as described previously (23). Total RNA RT-PCR section uses intercalating dye SYBR ${ }^{\circledR}$ green (Thermo Scientific Maxima/SYBR ${ }^{\circledR}$ Green/ROX) in presence of primer pairs. PCR mixture consisted of SYBR ${ }^{\circledR}$ Green PCR Master Mix including 10 pmol forward and reverse primers, and cDNA of samples in total $20 \mu \mathrm{L}$. GAPDH was amplified for normalizing the efficiency of CDNA synthesis and the amount of RNA applied. PCR was performed with initial denaturation at $95^{\circ} \mathrm{C}$ for 5 -min, followed by amplification for 40 cycles, each cycle consisting of denaturation at $95{ }^{\circ} \mathrm{C}$ for 30 s, annealing at $57{ }^{\circ} \mathrm{C}$ for $30 \mathrm{~s}$, polymerization at $72{ }^{\circ} \mathrm{C}$ for $60 \mathrm{~s}$ and, polymerization at $72{ }^{\circ} \mathrm{C}$ for $5 \mathrm{~min}$. The results pertaining to ADAMTS1, 4, 5, 7, 15, 18, and TIMP-3 were represented as graphics. The bars and error bars represent means and standard deviations (SD) of amplicon concentrations.

Gradient/conventional PCRs: Although primers purchased were supplied with theoretical Tm, we calculated the annealing temperature of the thermal cycling reaction for our assays. As the starting point, a gradient was set up so that it spans the calculated annealing temperature of the primers approximately $\pm 10^{\circ} \mathrm{C}(51.0,52.7,55.3,58.5,61.2$, and 62.9 $\left.{ }^{\circ} \mathrm{C}\right)$. PCR was performed in the same conditions as stated above by using BioRad T-100 Thermal Cycler. Once the 
Table 2: The primary and secondary antibodies used in Western blotting tests for A disintegrin and metalloproteinases with thrombospondin type 1 motifs (ADAMTS) and tissue inhibitors of metalloproteinases (TIMP) proteins and their technical details (Ab: Antibody, kDa: kilo dalton).

\begin{tabular}{|c|c|c|c|c|c|c|c|}
\hline No & Primary Ab & Concentration & Secondary $\mathbf{A b}$ & Concentration & Reaction & kDa & Catalogue no \\
\hline 1 & ADAMTS1 & $1 / 1000$ & Mouse & $1 / 4000$ & Mouse, Rat, Human & $85-110$ & sc-47727 \\
\hline 2 & ADAMTS4 & $1 / 1000$ & Rabbit & $1 / 4000$ & Mouse, Rat, Human & $68-55$ & sc-25582 \\
\hline 3 & ADAMTS5 & $1 / 1000$ & Rabbit & $1 / 4000$ & Mouse, Rat, Human & $75-105$ & sc-134952 \\
\hline 4 & ADAMTS7 & $1 / 1000$ & Goat & $1 / 4000$ & Mouse, Rat, Human & $55-70$ & sc- 163642 \\
\hline 5 & ADAMTS15 & $1 / 1000$ & Goat & $1 / 4000$ & Mouse, Rat, Human & 103 & sc- 68441 \\
\hline 6 & ADAMTS18 & $1 / 1000$ & Goat & $1 / 4000$ & Mouse, Rat, Human, Dog & 135 & sc- 67707 \\
\hline 7 & TIMP-3 & $1 / 1000$ & Rabbit & $1 / 4000$ & Mouse, Rat, Human & 25 & sc-6836 \\
\hline 8 & TIMP-4 & $1 / 1000$ & Goat & $1 / 4000$ & Mouse, Rat, Human & 22 & sc-9375 \\
\hline \multicolumn{8}{|c|}{ Internal control } \\
\hline 9 & GAPDH & $1 / 10000-1 / 50000$ & Rabbit & $1 / 4000$ & Human & 36 & $A b-128915$ \\
\hline
\end{tabular}

experiment has ended, the samples were run and visualized on an agarose gel (2\%) to assess the results. The optimal annealing temperature and primer combination was given to the band with the highest intensity (yield) with no nonspecific products. The calculated Tm values by gradient PCR were given in Table 1.

Protein isolation, Immunoblotting and Antibodies: Anti-ADAMTS1, Anti-ADAMTS4, Anti-ADAMTS5, AntiADAMTS7, Anti-ADAMTS15, Anti-ADAMTS18, Anti-TIMP-3, Anti-TIMP-4, and Anti-GAPDH primary antibodies were purchased from Santa Cruz Biotechnology, Inc., CA and used at a 1:1000 dilution. Cross-reactivity was confirmed before the study to match with data that described on the manufacturer's data sheet. The cells were washed once with phosphate-buffered saline and scraped from the plates. Cells were solubilized in $300 \mu \mathrm{L}$ of CelLytic M (Sigma Aldrich, St. Louis, MO) with a protease/phosphatase inhibitor (Pierce Protease and Phosphatase Inhibitor Mini Tablets, EDTA Free, Thermo Fisher Sci.). After incubation in at $4{ }^{\circ} \mathrm{C}$ for $15 \mathrm{~min}$, the samples were centrifuged (15 min, 12,000xg). The protein concentration of cell extracts was determined using Thermo Scientific Bradford Assay kit and BSA as standard. Protein samples were boiled at $95{ }^{\circ} \mathrm{C}$ in Laemmli sample buffer (BioRad) and $\beta$-mercaptoethanol for $8 \mathrm{~min}$. Ten micrograms of total protein were run in Western blotting (WB) tanks. Briefly, 10 $\mathrm{LL}$ of each sample including protein marker (BioRad Precision Plus Protein Western C Standard) were loaded to WB gel (BioRad Mini PROTEAN TGX Stain Free Gels, 4-15\%, 15-well comb, $15 \mu \mathrm{L}$ ) in BioRad 1XTris/Glycerine/SDS running buffer and run at $250 \mathrm{~V}$ for $20 \mathrm{~min}$. After electrophoresis, proteins were transferred onto PVDF membranes (BioRad Trans-Blot Turbo Transfer Pack, $0.22 \mu \mathrm{M}$ ) (BioRad, Singapore). Membranes were blocked for one hour in $2.5 \%$ nonfat dried skim milk in Tris-buffered saline containing of $0.05 \%$ Tween-20. The membranes were incubated overnight with primary antibodies (Table 2) diluted in blocking buffer. After washing with Tris-buffered saline/Tween 20 (thrice) for $8 \mathrm{~min}$. each at room temperature, the membranes were incubated for one hour with the secondary antibodies (Table 2). Following three successive washes, immunoreactive bands were visualized using enhanced chemiluminescence system (BioRad Immun-Star Western C kit) for 90s. Signals were detected with BioRad ChemiDoc MP Imaging System (Singapore), and the densitometry was performed with Image-J software and normalized to the signal intensity of GAPDH for equal protein loading control of each sample in each experiment. This quantification was performed with the linear range of the standard curve defined by the standard GAPDH, for all densitometry analysis.

Statistical Analysis: Statistical Package for Social Studies (SPSS) version 16.0 was used for statistical tests. Nonparametric Kruskal Wallis Test was applied. The relationships between the variables were tested by Mann Whitney$\mathrm{U}$ test. $\mathrm{P}<0.05$ was accepted as significant.

\section{RESULTS}

In order to assess the effects of insulin on ADAMTS gene expression in cultured OUMS-27 cells, qRT-PCR was performed on mRNA eluted from cell lysate. Quantitation and standard curves as well as other data of qRT-PCR instrument were regular and flawless. On the other hand, in order to achieve a better understanding of the mechanism of insulin on cartilage matrix degradation, we analyzed ADAMTS proteins in cultured OUMS-27 cells in vitro. WB analysis of ADAMTS proteins using antibodies, which recognize specific enzyme proteins of ADAMTS, was performed. In the graphics of WB analysis, $x$-axis shows insulin application time intervals (in days), $y$-axis shows band densities of ADAMTS and TIMP proteins normalized by GAPDH densities. There is no numeric value of this ratio.

ADAMTS1/GAPDH graphic is shown in Figure 1A. From quantitative nucleic acid concentration graphics, cDNA concentration of D1, D7 and D11 groups was rather low compared to that of control group $P=0.047,0.009,0.009$, and 

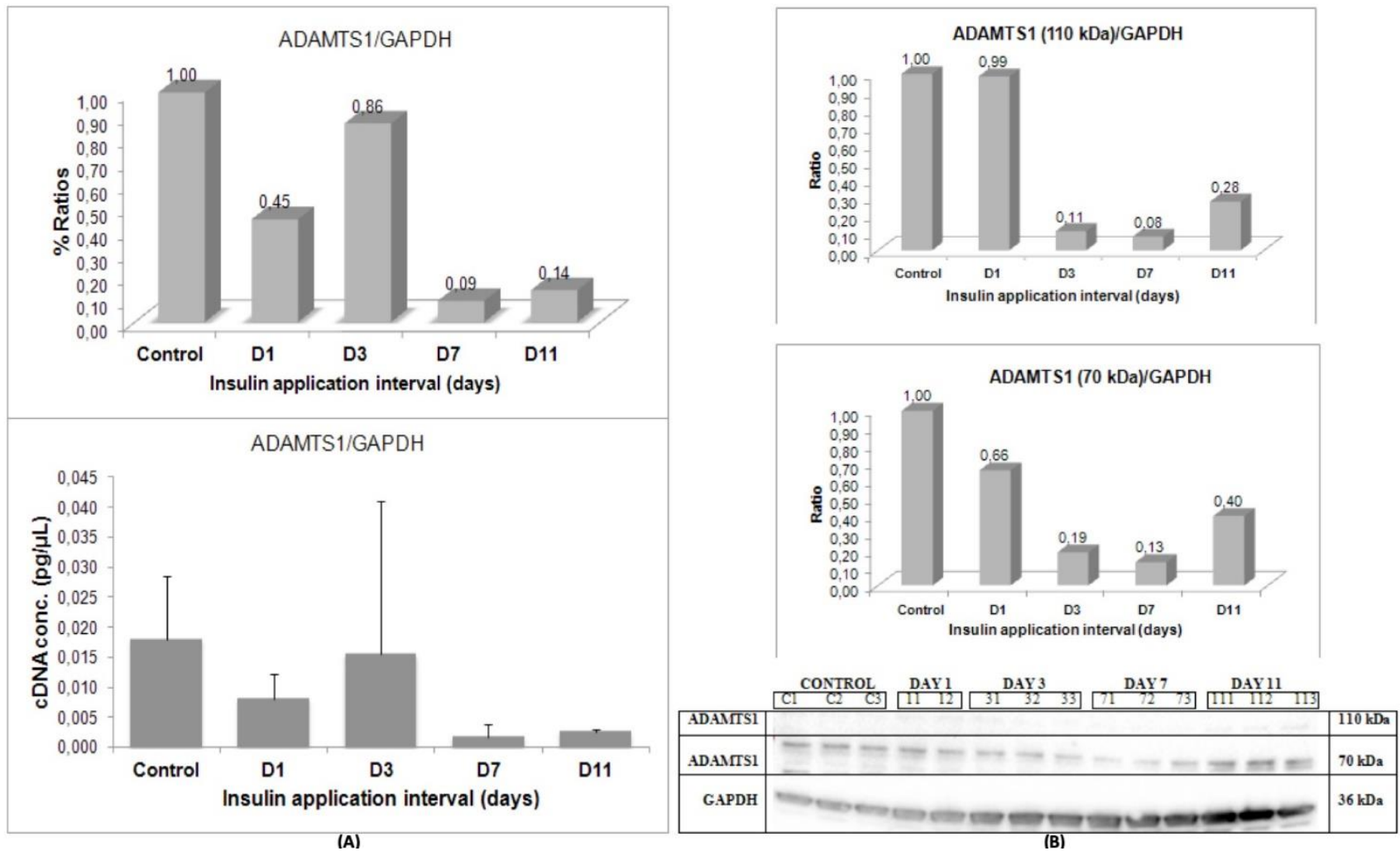

Figure 1: (A) qRT-PCR test results of A disintegrin and metalloproteinases with thrombospondin type 1 motif 1 (ADAMTS1) in OUMS-27 chondrosarcoma cells. Values were standardized and normalized by proportioned with GAPDH values. Bars and error bars represent mean values and standard deviations, respectively. There were statistically significant differences between Control-Day 1 study group (C-D1), C-D7, C-D11, and D1-D7 ( $P=0.047,0.009,0.009$, and 0.028 respectively). (B) The electrophoretic image of ADAMTS1 protein of OUMS-27 cells by Western blotting technique and their graphics (two different bands) obtained by the calculation of band densities by CCD camera and ImageJ program. The $x$-axis shows insulin application time intervals (in days) and $y$-axis shows band densities of ADAMTS1. The densities for ADAMTS1 were normalized with GAPDH densities.

0.028 , respectively). It generally means that insulin application lead to a decrease in amplicon levels of ADAMTS1. There was also a statistically significant difference in amplicon concentrations between D1 and D7 groups $(P=0.028)$ (Figure 1A).

It seems that ADAMTS1 protein production was decreased upon insulin induction in OUMS-27 cells. Immunoreaction between antibodies and proteins attached to the membranes revealed two bands: $110 \mathrm{kDa}$ and $70 \mathrm{kDa}$. It was suggested that similar bands could be found after protein degradation. According to the manufacturer's instruction and the related scientific publications, the second band was being expected around $85 \mathrm{kDa}$. The bands shown on $110 \mathrm{kDa}$ and $70 \mathrm{kDa}$ were identified as preform (inactive) and proform (active), respectively. Protein levels at first day after insulin induction were the same compared to control group. There was a dramatic decrease on D3, then the decrease continues up to D7. Although ADAMTS1 level increases on D11, the level was still about one fourth of the beginning level (Figure 1B).

The results of ADAMTS4 nucleic acid concentration are given in Figure 2A. Nucleic acid concentrations were decreased in D1 group and increased in D3, D7, and D11 groups compared to control group. However, as seen from high-rise SD bars, there were no significant differences between study and control groups (Figure 2A). 


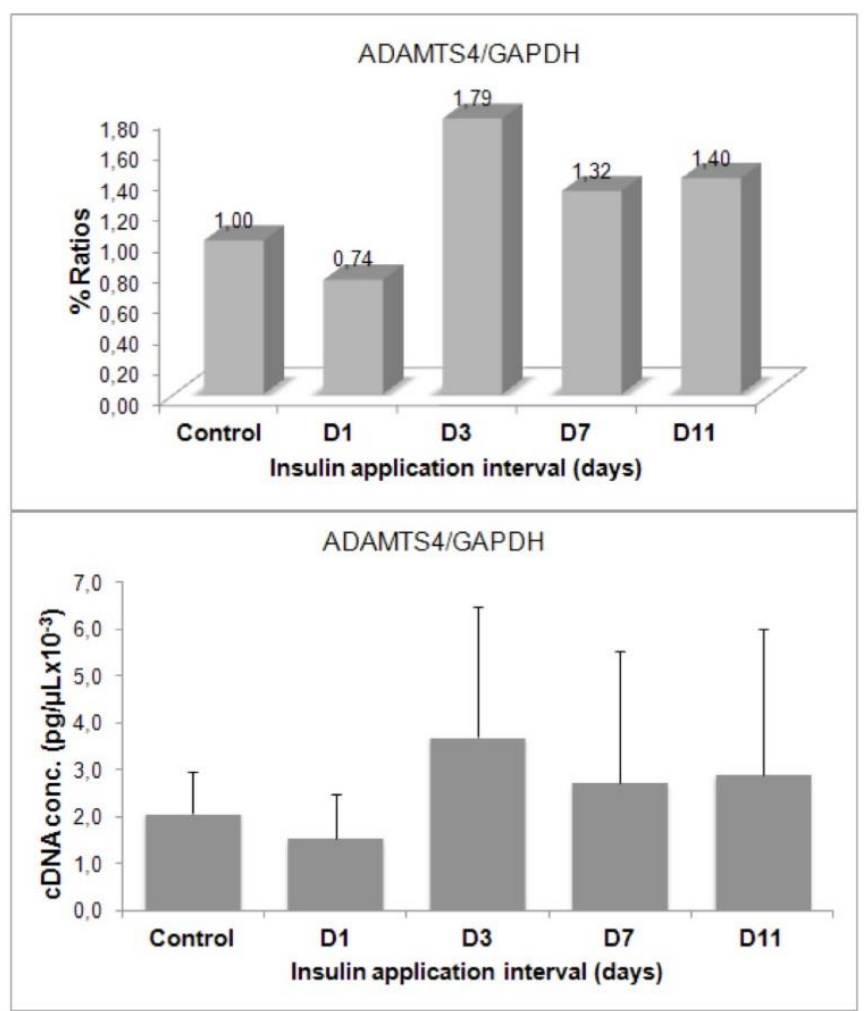

(A)
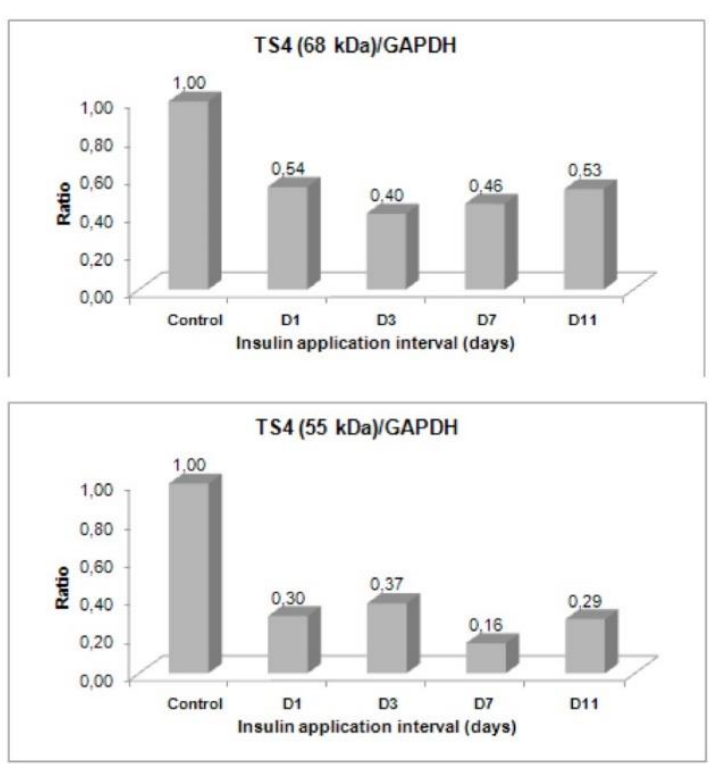

CONTROL DAY 1 DAY 3 DAY 7 DAY 11

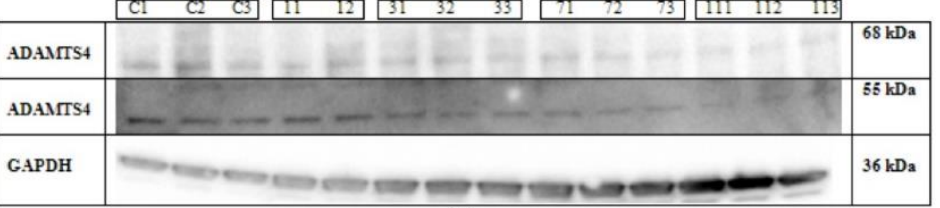

(B)

Figure 2: (A) qRT-PCR test results of $A$ disintegrin and metalloproteinases with thrombospondin type 1 motif 4 (ADAMTS4) in OUMS-27 chondrosarcoma cells. Values were standardized and normalized by proportioned with GAPDH values. Bars and error bars represent mean values and standard deviations, respectively. There were no statistically significant differences between the groups. (B) The electrophoretic image of ADAMTS4 protein of OUMS-27 cells by Western blotting technique and their graphics (two different bands) obtained by the calculation of band densities by CCD camera and ImageJ program. The $x$-axis shows insulin application time intervals (in days) and $y$-axis shows band densities of ADAMTS4. The densities for ADAMTS4 were normalized with GAPDH densities.

The antibody used for ADAMTS4 protein detection gave two bands on $68 \mathrm{kDa} / 55 \mathrm{kDa}$. At the D1 of insulin application, ADAMTS4 protein level decreased sharply. The decreases of protein amount for first band continued up to D3 and then started to increase from D7. Regarding the second band, the decrease observed on day- 1 was permanent/constant up to D11 (Figure 2B).

Quantitative nucleic acid concentrations of ADAMTS5 in D1, D3, D7, and D11 groups were decreased compared to control, but only D1 and D7 values were significant $(P=0.009$ and $P=0.016$, respectively) (Figure 3A). It generally means that the application of insulin led to a crucial decrease in mRNA amount of ADAMTS5 in at least two study groups. It could not be observed for D3 and D11 groups. Furthermore, there were statistically significant differences of amplicon concentration between D1-D11 and D7-D11 ( $P=0.009$ and $P=0.036$, respectively) (Figure 3A). 


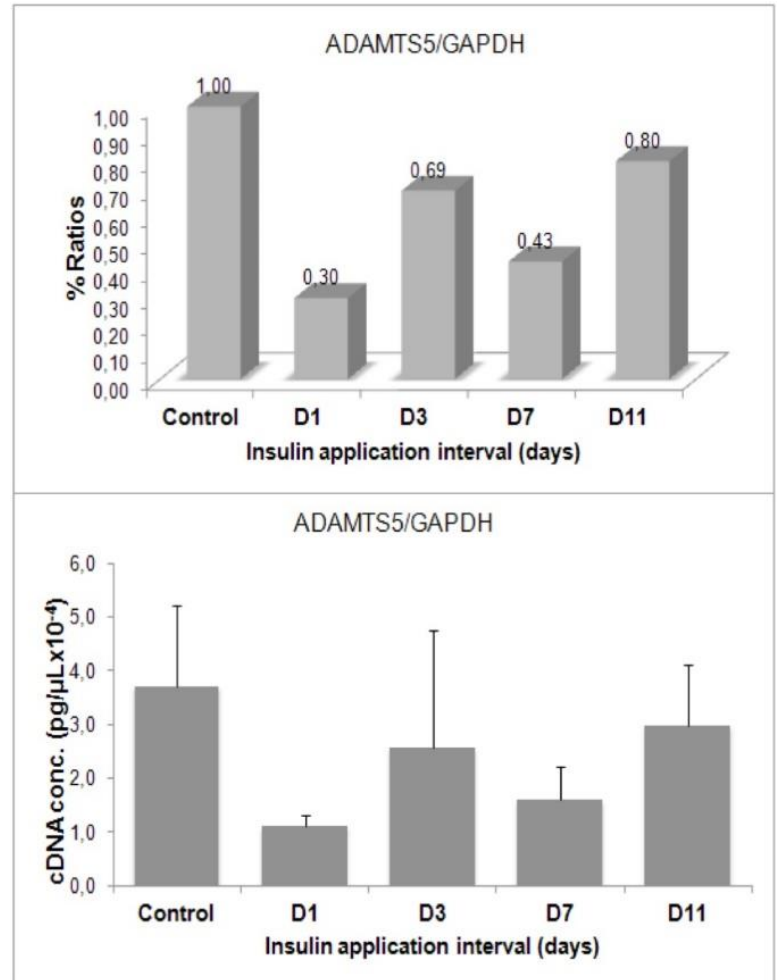

(A)

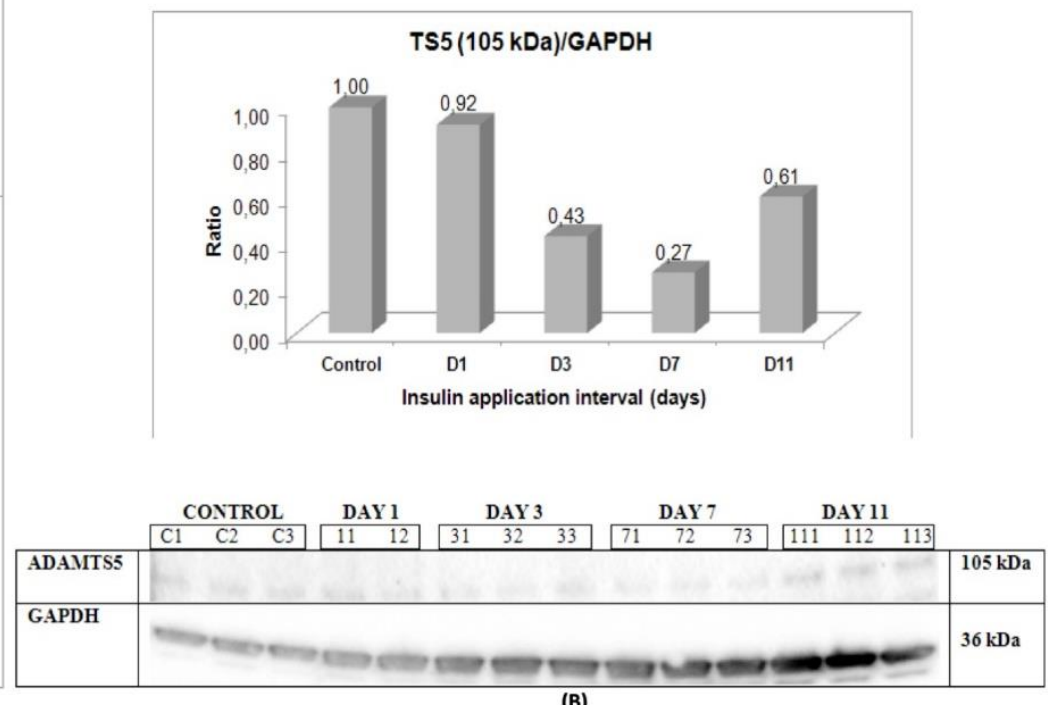

Figure 3: (A) qRT-PCR test results of A disintegrin and metalloproteinases with thrombospondin type 1 motif 5 (ADAMTS5) in OUMS-27 chondrosarcoma cells. Values were standardized and normalized by proportioned with GAPDH values. Bars and error bars represent mean values and standard deviations, respectively. There were statistically significant differences between Control-Day 1 study group (C-D1), C-D7, C1-D11, and D7-D11 ( $P=0.009,0.016,0.009$, and 0.036 respectively). (B) The electrophoretic image of ADAMTS5 protein of OUMS-27 cells by Western blotting technique and its graphic (one band) obtained by the calculation of band density by CCD camera and ImageJ program. The $x$-axis shows insulin application time intervals (in days) and $y$-axis shows band densities of ADAMTS5. The density for ADAMTS5 was normalized with GAPDH densities.

Although the antibody used for ADAMTS5 protein showed two bands at $105 \mathrm{kDa} / 75 \mathrm{kDa}$, the second one could not be obtained properly. Thus, only $105 \mathrm{kDa}$ band was interpreted. The production of ADAMTS5 protein was decreased upon insulin induction in OUMS-27 cells. Protein levels were decreased gradually during the experiments up to D7. Band density was increased to some extent on D11 (Figure 3B).

Figure 4A shows the quantitation of nucleic acid concentration of ADAMTS7. Concentrations of D1 and D3 groups are quite similar to those of control group. Although there is an increase upon insulin induction in D1 group, it was not expected to be significant because of high SD. However, nucleic acid concentrations of D7 and D11 groups were significantly decreased $(P=0.009)$. It probably means that insulin application affected mRNA levels of ADAMTS7 proteins at least in two groups. It is not valid for D1 and D3 groups of cells. In addition to that, there were statistically significant differences in cDNA concentrations between D1-D7, D1-D11, D3-D11 ( $P=0.016,0.009$, and $P=0.050$, respectively) (Figure 4A). 


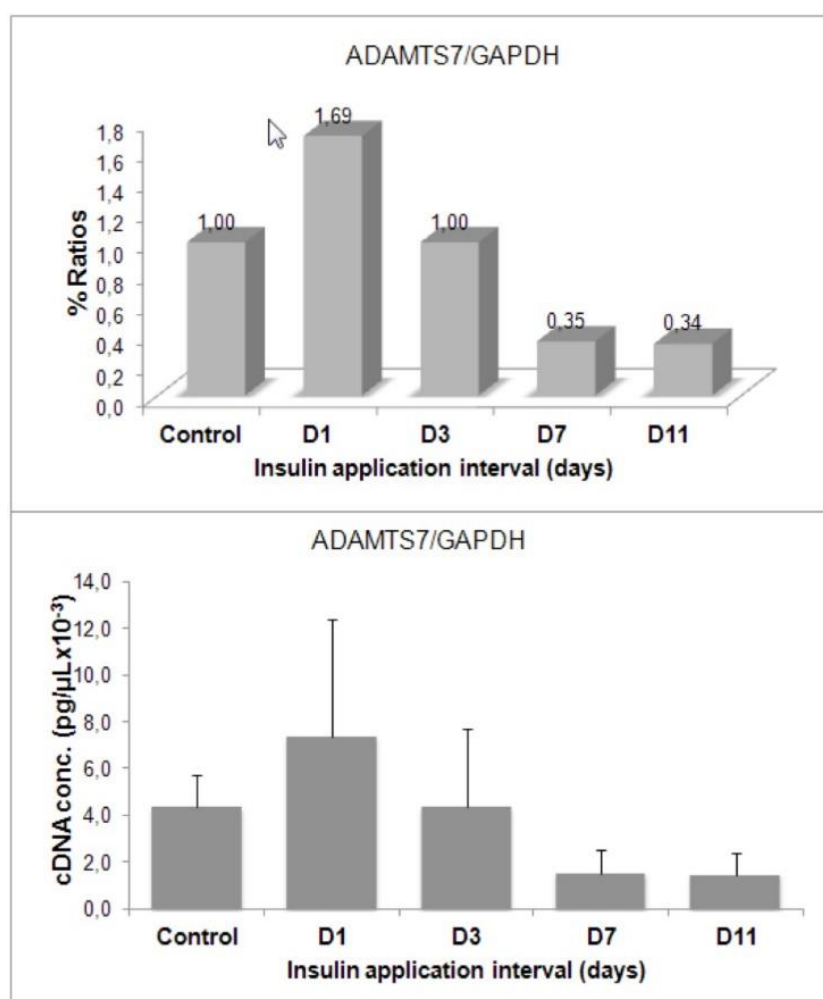

(A)
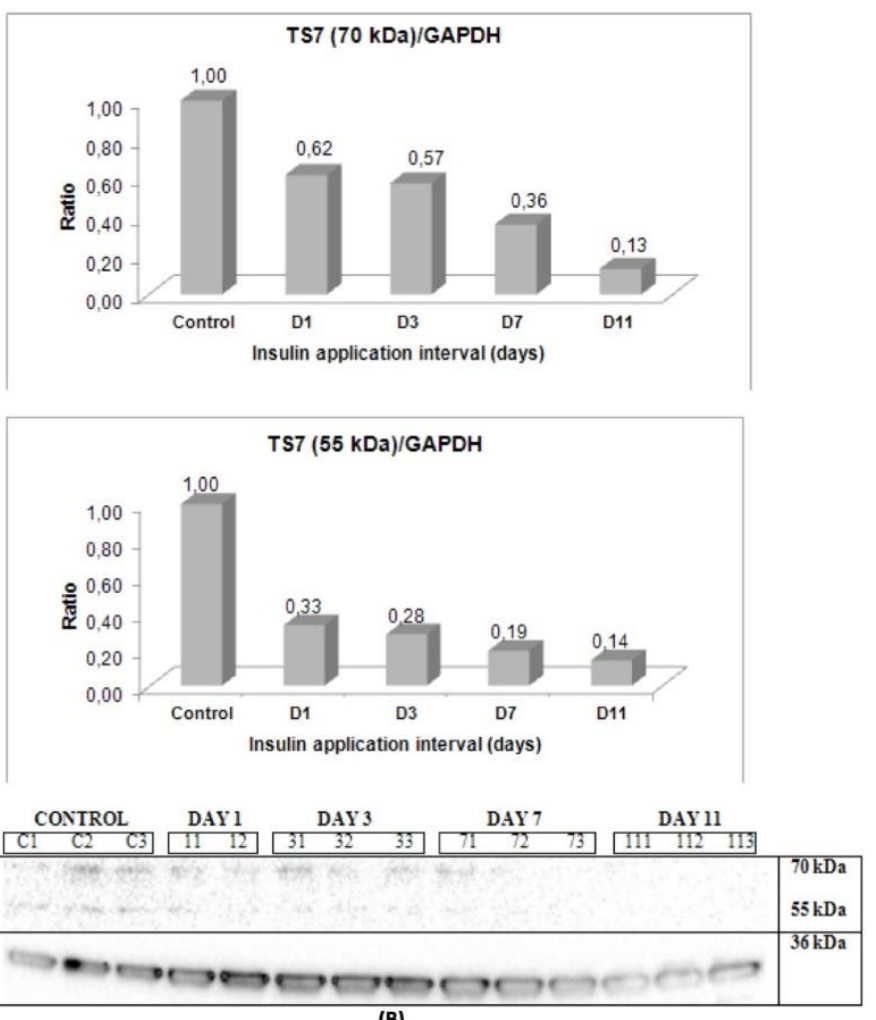

(B)

Figure 4: (A) qRT-PCR test results of A disintegrin and metalloproteinases with thrombospondin type 1 motif 7 (ADAMTS7) in OUMS-27 chondrosarcoma cells. Values were standardized and normalized by proportioned with GAPDH values. Bars and error bars represent mean values and standard deviations, respectively. There were statistically significant differences between Control-Day 7 study group (C-D7), C-D11, D1-D7, D1-D11, and D3-D11 ( $P=0.009,0.009,0.016,0.009$, and 0.050 respectively). (B) The electrophoretic image of ADAMTS7 protein of OUMS-27 cells by Western blotting technique and their graphics (two different bands) obtained by the calculation of band densities by CCD camera and ImageJ program. The $x$ axis shows insulin application time intervals (in days) and y-axis shows band densities of ADAMTS7. The densities for ADAMTS7 were normalized with GAPDH densities.

ADAMTS7 protein level was decreased dramatically during the experiment in OUMS-27 cells (there was a $40 \%$ decrease in protein amount of $70 \mathrm{kDa}$ band and $60 \%$ decrease for $55 \mathrm{kDa}$ at D1 of experiments compared to controls). There was a gradual decrease in both bands up to around $90 \%$ in D11 (Figure 4B).

The qRT-PCR results of ADAMTS15 is presented in Figure 5A. Although there were some differences in quantitative nucleic concentrations of groups D1 (increase), D3 (increase), D7 (decrease), and D11 (decrease) compared to control, they were statistically insignificant. As a conclusion, insulin application did not affect ADAMTS15 mRNA concentrations. 


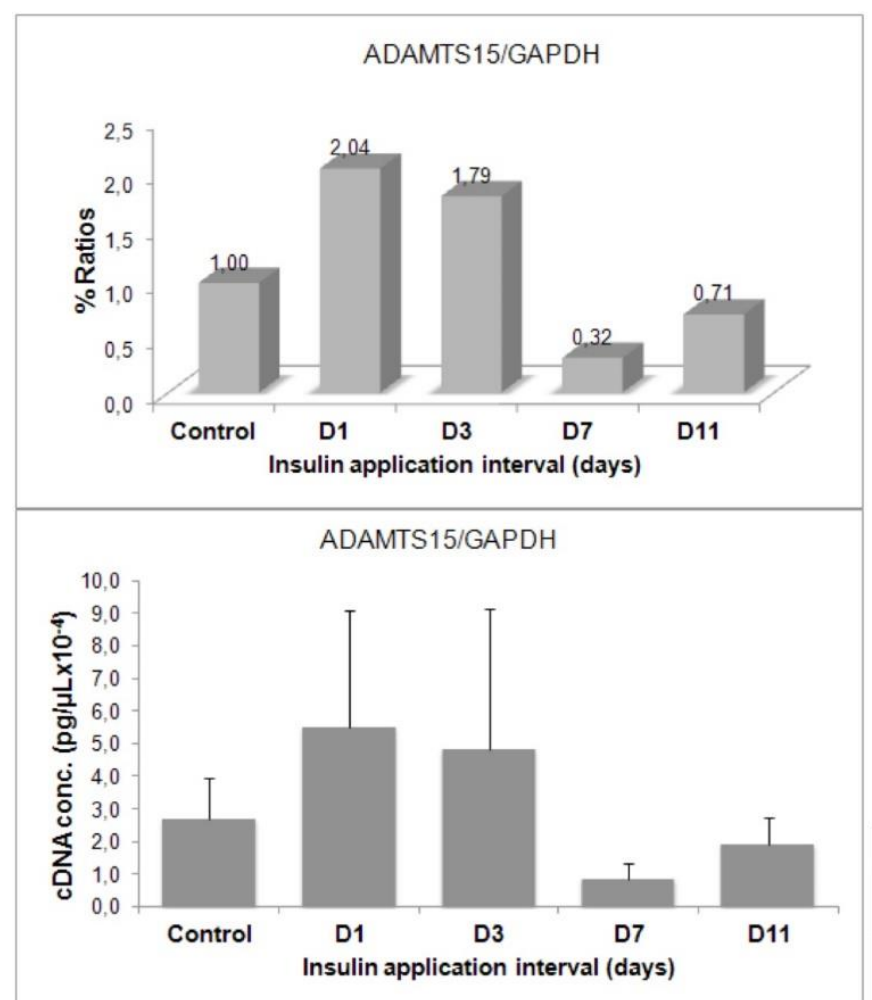

(A)
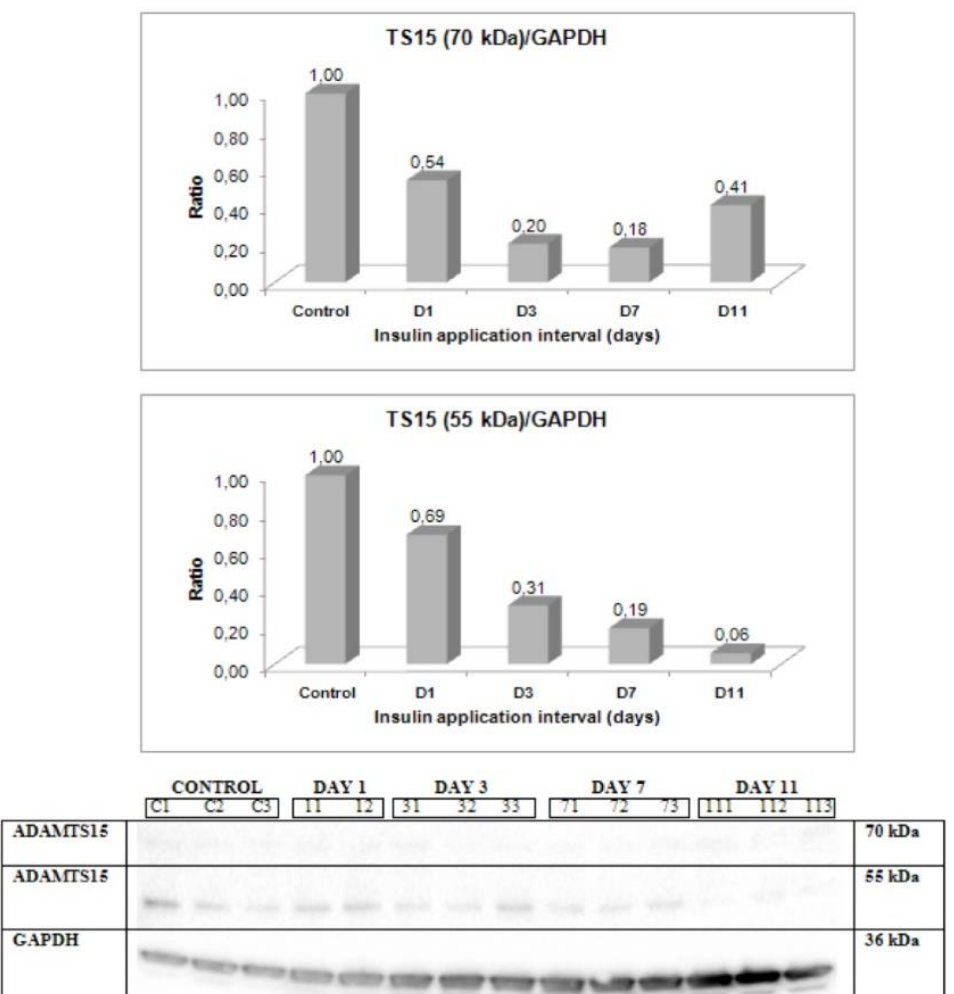

(B)

Figure 5: (A) $q R T-P C R$ test results of $A$ disintegrin and metalloproteinases with thrombospondin type 1 motif 15 (ADAMTS15) in OUMS-27 chondrosarcoma cells. Values were standardized and normalized by proportioned with GAPDH values. Bars and error bars represent mean values and standard deviations, respectively. There were no statistically significant differences between the groups. (B) The electrophoretic image of ADAMTS15 protein of OUMS-27 cells by Western blotting technique and their graphics (two different bands) obtained by the calculation of band densities by CCD camera and ImageJ program. The $x$-axis shows insulin application time intervals (in days) and $y$-axis shows band densities of ADAMTS15. The densities for ADAMTS15 were normalized with GAPDH densities.

There were two bands for ADAMTS15. The first band was anticipated at around 103 kDa according to prospectus whereas it was found at around $70 \mathrm{kDa}$. Two possibilities arise from this discrepancy: This band may originate from degradation of ADAMTS15 or it may be accepted as a nonspecific band. ADAMTS15 protein levels were affected by insulin in OUMS-27 cells. At the first and subsequent days, protein amounts were decreased gradually up to D7. After that day, $55 \mathrm{kDa}$ band continued to decrease, but $70 \mathrm{kDa}$ band showed an increase up to those levels of D1 (Figure 5B).

There was a gradual increase in ADAMTS18 nucleic acid concentrations of groups D1, D3, D7, and D11 in OUMS-27 cells induced by insulin (Figure 6A). Because there were great differences between the individual results, statistical analyses gave no difference between study groups and control group. 


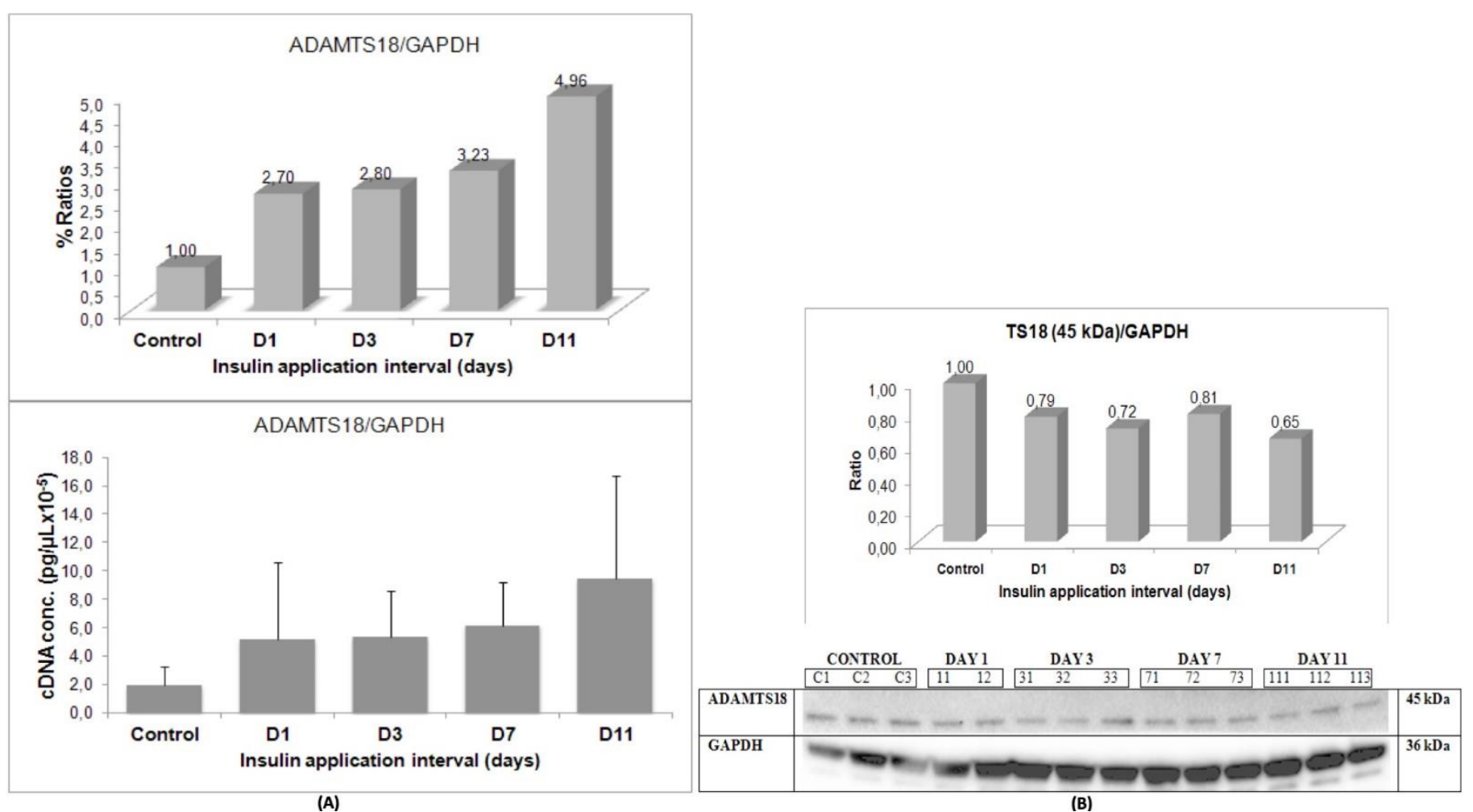

Figure 6: (A) $q R T-P C R$ test results of $A$ disintegrin and metalloproteinases with thrombospondin type 1 motif 18 (ADAMTS18) in OUMS-27 chondrosarcoma cells. Values were standardized and normalized by proportioned with GAPDH values. Bars and error bars represent mean values and standard deviations, respectively. There were no statistically significant differences between the groups. (B) The electrophoretic image of ADAMTS18 protein of OUMS-27 cells by Western blotting technique and its graphic (one band) obtained by the calculation of band density by CCD camera and Images program. The $x$-axis shows insulin application time intervals (in days) and $y$-axis shows band densities of ADAMTS18. The density for ADAMTS18 was normalized with GAPDH densities.

The antibodies used for detection of ADAMTS18 in OUMS-27 cells gave three bands in WB: two (100 kDa and 75 $\mathrm{kDa}$ ) of them were considered to be nonspecific bands. The smallest band, around $45-50 \mathrm{kDa}$, was considered to be the active form of enzyme. The decrease in the protein amount of ADAMTS18 upon insulin induction was found to be negligible when compared to other ADAMTS proteins. There was a $30 \%$ decrease on the first day of insulin induction, and then it remained stable around this percentage during 11 days of experiment (Figure 6B).

Although OUMS-27 cells produced 6 times more TIMP-3 protein in D1 after insulin induction compared to controls, it was not statistically significant because of a huge gap between lowest and highest values of instrument analyses. There was serious decrease in TIMP-3 cDNA levels after D3. The result of D3 was not statistically significant although a prominent (20\%) decrease was observed compared to control group. However, the decrease in nucleic acid concentration of groups D7 and D11 compared to control group was statistically significant ( $P=0.017$ and 0.047 , respectively). Therefore, the insulin application led to the decrease in TIMP-3 mRNA levels in OUMS-27 cells. This is not valid for D1 and D3 groups. Besides, there were significant differences in CDNA concentrations between D1-D7, D1-D11, and D3-D7 groups $(P=0.016,0.021$, and $P=0.028$, respectively) (Figure 7A). 


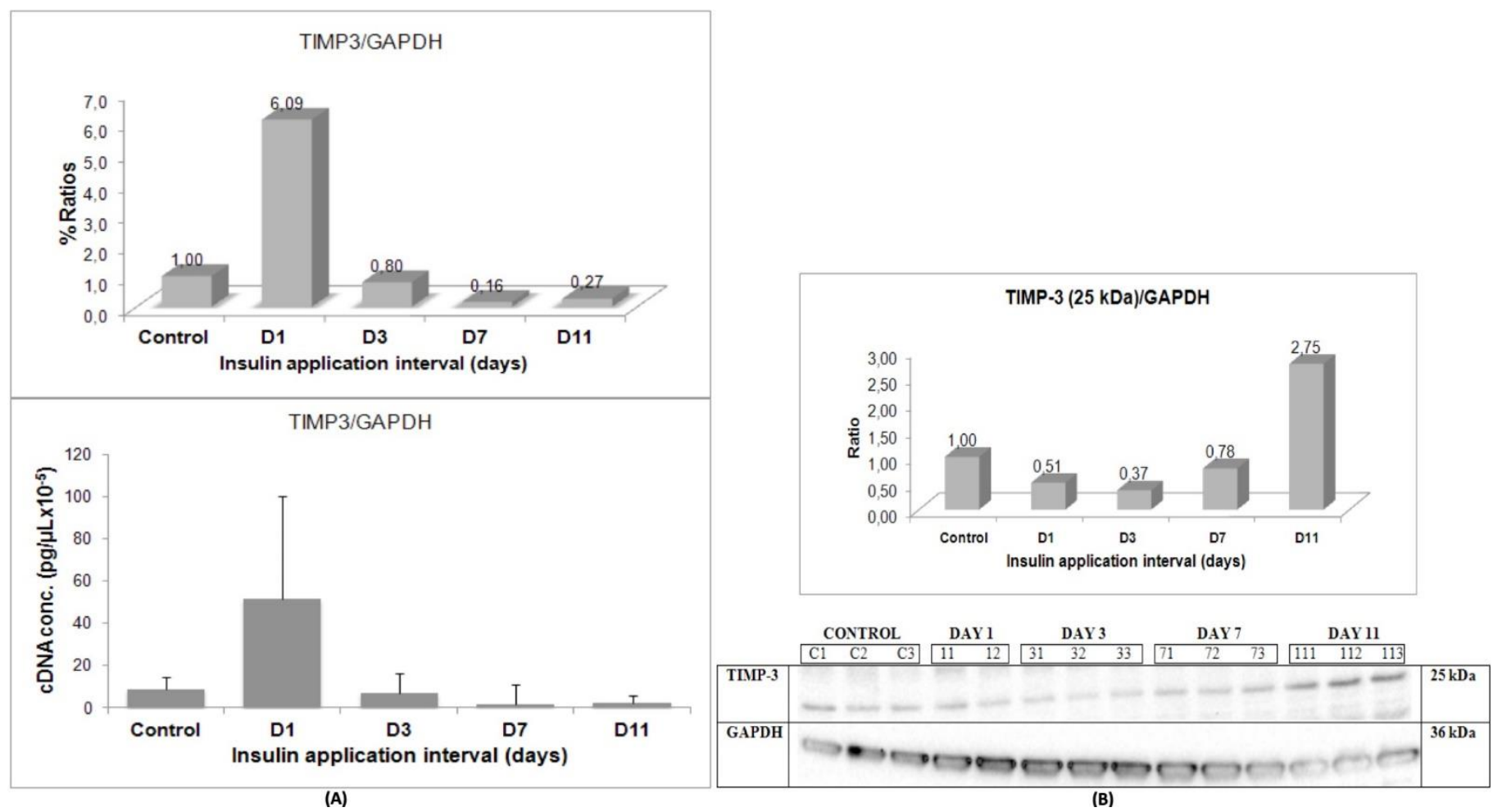

Figure 7: (A) $q R T-P C R$ test results of the tissue inhibitors of metalloproteinases-3 (TIMP-3) in OUMS-27 chondrosarcoma cells. Values were standardized and normalized by proportioned with GAPDH values. Bars and error bars represent mean values and standard deviations, respectively. There were statistically significant differences between Control and Day 7 study group (C-D7), C-D11, D1-D7, D1-D11, and D3-D7 ( $P=0.016,0.047,0.016,0.021$, and 0.028 respectively). (B) The electrophoretic image of TIMP-3 protein of OUMS-27 cells by Western blotting technique and its graphic (one band) obtained by the calculation of band density by CCD camera and ImageJ program. The $x$-axis shows insulin application time intervals (in days) and $y$-axis shows band densities of TIMP-3 protein. The density for TIMP-3 was normalized with GAPDH densities.

The bands of TIMP-3 were detected around $25 \mathrm{kDa}$. Insulin induction led to a marked increase in TIMP-3 protein amount in OUMS-27 cells. When compared to control group, protein levels were decreased $49 \%$ on D1, $63 \%$ on D3, and $22 \%$ on D7 and finally protein amount suddenly showed a 2.75 fold increase compared to control values (Figure 7B).

TIMP-4 bands were detected around $22 \mathrm{kDa}$. The effect of insulin on TIMP-4 proteins in OUMS-27 cells was limited. Insulin induction during all 11 days led to an increase of merely $10 \%$. The levels of TIMP-4 protein on other harvesting days were almost the same as those of control group (Figure 8). 


\section{TIMP-4 (22 kDa)/GAPDH}
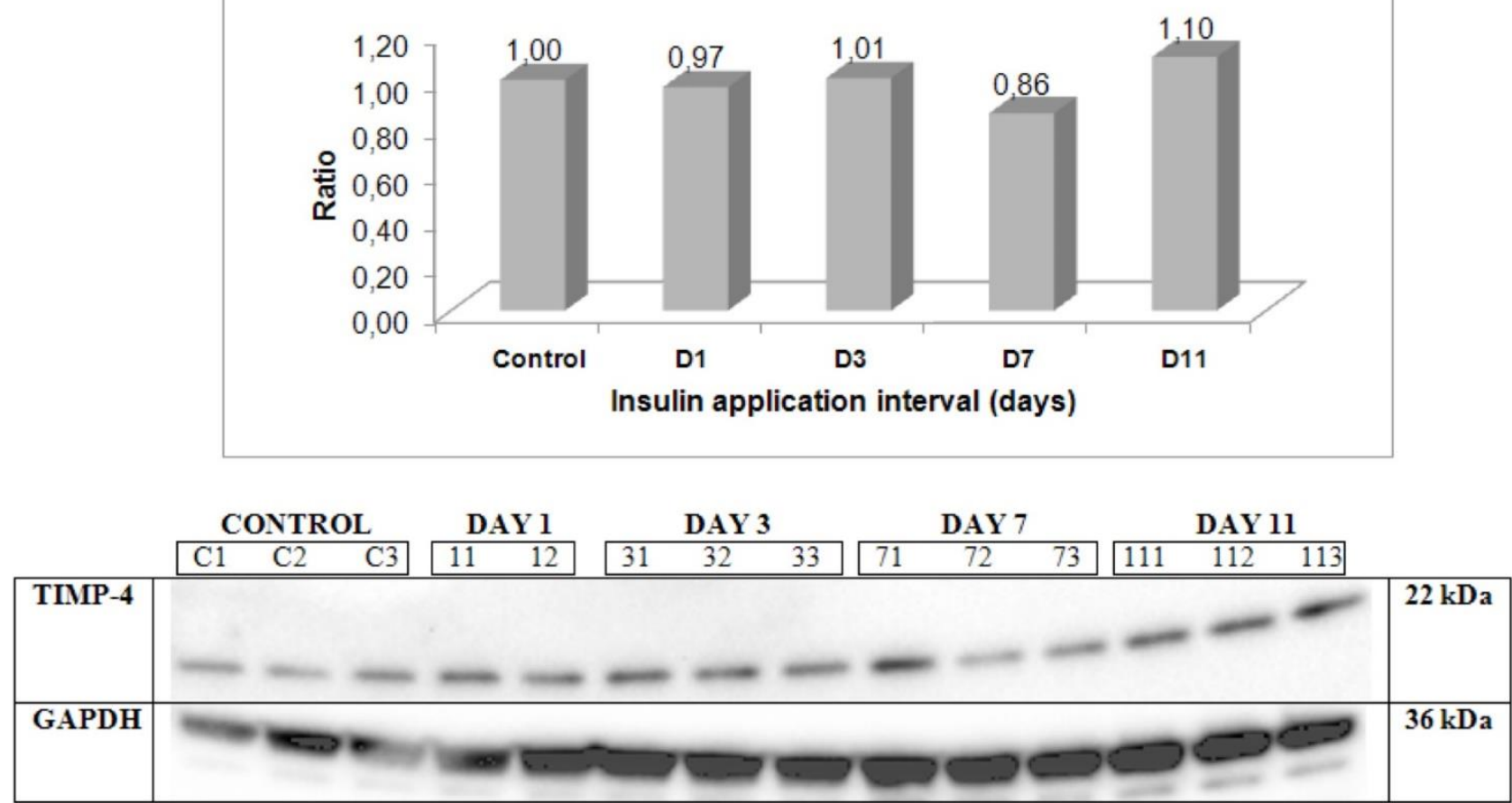

Figure 8: The electrophoretic image of the tissue inhibitors of metalloproteinases-4 (TIMP-4) protein of OUMS-27 chondrosarcoma cells by Western blotting technique and its graphic (one band) obtained by the calculation of band density by CCD camera and ImageJ program. The x-axis shows insulin application time intervals (in days) and y-axis shows band densities of TIMP-4 protein. The density for TIMP-4 was normalized with GAPDH densities.

At a glance, the WB and qRT-PCR results overlap at some points and show differences in others. For example, while $\mathrm{mRNA}$ and protein measurements show parallelism in terms of ADAMTS1, 5 and 7 concentrations, the mRNA and protein levels show differences in terms of TIMP-3. It has been observed that some changes in the protein levels of other studied ADAMTS enzymes have not occurred in mRNA levels. For example, ADAMTS4 protein decreased gradually after the application of the insulin. This gradual reduction is present in both observed bands. If we only compare the control and D11 groups, we can see a half reduction on the first and a nearly 3 -fold reduction on the second band. No difference is found in the qRT-PCR results between the control and insulin-induced group. It is the same for ADAMTS15. In fact, the results are more dramatic here. The reduction on the $55 \mathrm{kDa}$ band is more than 10 times in the D11 insulin-induced group. A 40\% reduction in the D1 group, a 3-fold reduction in the D2 group and a 5 -fold reduction in the D7 group are present. Although not as severe as that in $70 \mathrm{kDa}$ band, when the D11 group is considered, the two-fold reduction attracts attention. If we compare the qRT-PCR results of ADAMTS15 of the control and insulin groups, the differences appear to be statistically insignificant. In other words, no significant difference is observed in the mRNA levels. In addition to this, the ADAMTS18 results of the WB and qRT-PCR analyses have again revealed to be parallel. In both methods, no significant differences have been found between the control and insulin groups. Because TIMP-4 has only been examined with the WB method, it has not been possible to compare the results. As for the differences of ADAMTS4 and 15 between the two methods; the cells have maintained their mRNA levels in the insulin and non-insulin groups up to the protein phase, but after that the protein stayed intact in the insulin-free environment whereas the level decreased due to digestion of the protein because of insulin induction. This result actually brings a different aspect of the original agenda: Insulin may be acting as a controlling regulator of the digestion of these proteins.

\section{DISCUSSION}

In this experimental study, we investigated the effects of insulin in chondrosarcoma cells in vitro. Since the study was performed in an immortal cancerous cell line in vitro, it is essential to refrain from overinterpretations and to be cautious when conducting and extrapolating these findings in vivo and disease conditions. However, it is also essential to connect the basic findings with real disease conditions in order to give an objective estimation to the readers. The obtained positive and/or negative findings of PCR and WB are important in several aspects and might be qualified as original: 1 ) 
Because our experiment was conducted in a way that the induction of insulin to the cells was investigated and the absence/ineffectiveness of insulin in DM was considered as a precondition, the exact opposite of our findings should be considered. In this case, there should be two changes; the intracellular matrix degrading enzymes would be activated and their inhibitory enzymes would become passive. These two findings make this study unique, because molecular causes of fracture healing problems in DM have a potential for further research. There might be some clues in our findings to reveal the molecular mechanisms of the fracture healing problems in DM. 2) The main reason for increased fragility of long bones in patients with uncontrolled DM may be absence and/or ineffectiveness of insulin. The reducing and/or inhibitory effects of insulin on ADAMTS proteins, ensure that the cartilage and bone tissues prefer to go to anabolic direction. In insulin absence, it can be anticipated that an increase in ADAMTS activity may accelerate the destruction of ECM in cartilage and bone tissues, leading consequently to a reduction in the resilience to bone fractures.

Little is known about the effect of DM on the cartilage phase of fracture healing. This phase plays an important role in the reparation process because the cartilage acts as a template for the subsequent bone formation (24). Our study has proven the reducing effect of insulin on three ADAMTS and the increasing effect on TIMP protein, and also sheds light on the molecular basis of deterioration of cartilage and bone repair in diabetes. Previous studies have shown that diabetic animals create a fracture callus, but the volume compared to that in normal animals is much smaller (25). Clinical and case studies have reported that diabetes delays fracture healing and dramatically increases recovery time (26). Animal studies have shown that DM causes the formation of small calluses resulting in the reduction of bone and cartilage development, reduces the proliferation and differentiation of osteoblastic cells and chondrocytes and that the mechanical strength is reduced two times during fracture reparation $(9,16)$. An important decrease of collagen content in the callus has been identified in diabetic animals compared to normoglycemic animals (16). In an experimental study, during the healing of a tibial fracture, an unidentified catabolic effect and accelerated cartilage loss in the diabetic group was determined (27).

When insulin is induced into SRC chondrocyte cells, the insulin receptors have increased and this is not interpreted as an increase in the de novo receptor synthesis or a translocation of other intracellular receptors located in the cell compartments to the cell surface, but most likely as a decrease in the rate of receptor degradation (28). Chondrocytes synthesize and secrete the macromolecules forming the ECM of cartilage cells. SRC chondrocytes respond in a very special way to physiological concentrations of porcine insulin at in vitro conditions and produce plenty of cartilage-like proteoglycans (29), type-II-collagen (30), hyaluronic acid (31) and other secreted proteins (32). Rat chondrosarcoma chondrocytes are insulin- and IGF-1-dependent tumors. This tumor, shrinks significantly in hypophysectomized rats and also shows a distinct decrease in rats with streptozotocin-induced diabetes (33).

ADAMTS4/5 undertakes important roles in the degradation of the cartilage matrix proteoglycan (34). These enzyme levels drastically increase in animals with DM (35) and proteoglycans are removed very rapidly from the ECM. However, this process is slowed down with insulin therapy. Parallel to that, when insulin has been applied into chondrocyte cells as in our study, the levels/activity of these proteins have decreased and the removal of the proteoglycan groups have slowed down. We can provide a similar effect by directly introducing insulin into chondrosarcoma cells, so when viewed in terms of protein, we see that ADAMTS4 and 5 decrease drastically.

To understand the disorders occurring during increased fragility of long bones and delay in healing of fractured bones, the endochondral ossification process needs to be well analyzed. The cartilage matrix is digested during endochondral ossification. Studies in recent years related to the proteolytic enzymes, which could be responsible for the digestion, are based on two important main structures of the cartilage matrix proteins, type-ll collagen and aggrecan digesting proteinases. Fibrillary collagen and aggrecan digesting MMP13 inside the growing cartilage are especially expressed in hypertrophic chondrocytes (36). The chondrocytes undergo regular hypertrophy in MMP13 knockout mice, but the end of hypertrophic chondrocytes expands and the leading ossification invasion delays (37). The extinction of the MMP13 protein as a result of a mutation in the MMP13, results in a growth defect called Missouri-type spondylometaphyseal dysplasia (38). Contrary to MMP13, MMP9 does not digest native fibrillar collagen, but can digest denatured collagen and aggrecan (36). The deletion of both MMP9 and MMP13 genes in mice results in huge delay during ossification compared to the situation in which only one deletion in either MMP9 or MMP13 genes takes place (37). ADAMTS1, 4 and 5 knockout mice can grow up normal and do not show any defect in the cartilage $(39,40)$. Because these are the most important aggrecanases found in the cartilage, none of them takes part alone in the removal of cartilage aggrecan in a significant amount. Various enzymes belonging to the MMP and ADAMTS families are able to function interchangeably, thus if any single ADAMTS gene undergo knockout, another can fill its place to avoid growth 
defects. An alternative interpretation is the following: for a normal invasion premise of ossification, the removal of the fibrillar collagen is required, but the aggrecan removal is not important to this process.

One of the most important proteins in our study, the ADAMTS1 gene, has initially been cloned as a gene that is responsive to inflammation (41). It is not expressed in normal tissues but induced by lipopolysaccharide stimulation. It has been shown that ADAMTS4 together with ADAMTS1 play a key role in versican proteolysis (42). When compared with MMPs, ADAMTS proteases recognize substrates such as procollagen and proteoglycans with a broader specificity (42). It has also been reported that ADAMTS1 acts with a different function as angiogenesis inhibitor (43). One interesting fact is that the matrix around the cells does collide to allow chondrocyte hypertrophy. The fact that neither MMP nor ADAMTS proteins prevent this process of genetic manipulation, leads us to think that other proteinases are responsible for this process. Cathepsins and calpains are candidates for such a role because they are expressed by chondrocytes and have matrix destructive activities (36).

TIMPs are important for various physiological process controls. These can be classified as cell invasion, angiogenesis, digestion of articular cartilage, trophoblast implantation, inner fold formation of mammary gland, and wound healing $(44,45)$. According to our results, the TIMP-3 levels were increased. qRT-PCR results do not support this finding. According to our WB results, the TIMP-3 level was increased. A significant decrease has been observed by D7 and 11 . This increase in protein level presents a parallelism in the decrease of the ADAMTS level. TIMP-3 blocks the tissue proteinases, the cartilage tissue ECM cannot be cleaved, and the structure remains intact. No study was found about the levels of TIMP-3 and 4 after insulin induction to compare present results. In this respect, our findings are original. Upon insulin application, the TIMP-3 level will rise, trigger the anabolic processes in cartilage and healing bone tissue, contributing to tissue strength. TIMPs are natural inhibitors of MMPs. Factors like cytokines, hormones, and many other factors, including growth factors, affect the metalloproteinase activity (45). There are a lot of biological factors that affect metalloproteinase activities, including cytokines, hormones, growth factors, and many others (45).

Aggrecan proteoglycan gives the cartilage features, such as strength against the pressure force, dynamic weightbearing function and an osmotic feature (46). The aggrecan, which is an incredibly complex macromolecule, is specific to the cartilage and intervertebral disc, and is an extremely hydrophilic proteoglycan that consists of glycosaminoglycan chains, containing about 100-chondroitin sulfate and 30-keratin sulfate chains (47). The breaking down of the aggrecan is one of the important indicators of osteoarthritis. In the analysis of synovial fluid of arthritis patients, it has been shown that the aggrecan is pathologically cut from the aggrecanase cutting field (48). Many members of the ADAMTS family cut the molecule in vitro at this cutting point (49): most effective ones are ADAMTS4 and 5. Both of them are expressed in the normal and osteoarthritic cartilage and the synovium (50). Their inhibition prevents the collapse of aggrecan in vitro (51). ADAMTS4/5 knockout mice phenotypically differ from wild-type rats. The results obtained from this study have lots of data that shed light on mechanisms of many joint diseases, especially osteoarthritis. The loss of aggrecan from the cartilage in joint pathologies is mainly a proteolytic process conducted by aggrecanases. In vitro studies with human recombinant ADAMTS4 (52) and ADAMTS5 (53) enzymes, have shown that aggrecan was preferably cleaved from the CS-2 part. According to our findings, insulin behaves in a direction that might be classified totally as cartilage protective.

These effects of insulin on the chondrosarcoma cells, which we have been discussing in details, whether it is turning hyperglycemia to its normal state or its direct effect on cells, can be listed as following: accelerating fracture healing, improving the resilience to bone breakage/fractures, providing the growth and development of skeletal structures in children and ensuring success with pre-operational processes in dental implant surgery. To further investigate the subject and to clarify the exact mechanism(s), it would be helpful to investigate the ADAMTS and TIMP in terms of gene, mRNA, and protein phases in animals with experimentally induced DM.

\section{ACKNOWLEDGEMENT}

This study was presented at American Society for Matrix Biology, ASMB 2014 Meeting, October 12 - 15, 2014, Marriott Key Center, Cleveland, OH, U.S.A. We thank T. Kunisada from Okayama University Graduate School of Medicine and Dentistry, Okayama, Japan, for kindly providing OUMS-27 cells.

\section{REFERENCES}

1. Mobasheri A, Richardson S, Mobasheri R, Shakibaei M, Hoyland JA. Hypoxia inducible factor-1 and facilitative glucose transporters GLUT1 and GLUT3: putative molecular components of the oxygen and glucose sensing apparatus in articular chondrocytes. Histol Histopathol. 2005;20(4):1327-38. 
2. Mangiavini L, Merceron C, Araldi E, Khatri R, Gerard-O'Riley R, Wilson TL, et al. Loss of VHL in mesenchymal progenitors of the limb bud alters multiple steps of endochondral bone development. Dev Biol. 2014;393(1):12436. https://doi.org/10.1016/j.ydbio.2014.06.013 PMid:24972088 PMCid:PMC4335807

3. Riddle RC, Clemens TL. Insulin, osteoblasts, and energy metabolism: why bone counts calories. J Clin Invest. 2014;124(4):1465-7. https://doi.org/10.1172/JCI75554 PMid:24642463 PMCid:PMC3973079

4. Sicca CM, Corotti MV, Sgarbosa SH, Cestari TM, Cavalcanti MG, Ferreira PM, et al. Comparative histomorphometric and tomographic analysis of maxillary sinus floor augmentation in rabbits using autografts and xenografts. J Biomed Mater Res B Appl Biomater. 2008;86(1):188-96. https://doi.org/10.1002/jbm.b.31005 PMid: 18161780

5. Xu H, Shimizu Y, Asai S, Ooya K. Grafting of deproteinized bone particles inhibits bone resorption after maxillary sinus floor elevation. Clin Oral Implants Res. 2004;15(1):126-33. https://doi.org/10.1111/j.16000501.2004.01003.x PMid:14731186

6. $\mathrm{Xu} \mathrm{H}$, Shimizu $\mathrm{Y}$, Onodera $\mathrm{K}$, Ooya K. Long-term outcome of augmentation of the maxillary sinus using deproteinised bone particles experimental study in rabbits. $\mathrm{Br} J$ Oral Maxillofac Surg. 2005;43(1):40-5. https://doi.org/10.1016/j.bjoms.2004.10.004 PMid:15620773

7. Nevins ML, Karimbux NY, Weber HP, Giannobile WV, Fiorellini JP. Wound healing around endosseous implants in experimental diabetes. Int J Oral Maxillofac Implants. 1998;13(5):620-9.

8. Lu H, Kraut D, Gerstenfeld LC, Graves DT. Diabetes interferes with the bone formation by affecting the expression of transcription factors that regulate osteoblast differentiation. Endocrinology. 2003;144(1):346-52. https://doi.org/10.1210/en.2002-220072 PMid:12488363

9. Beam HA, Parsons JR, Lin SS. The effects of blood glucose control upon fracture healing in the BB Wistar rat with diabetes mellitus. J Orthop Res. 2002;20(6):1210-6. https://doi.org/10.1016/S0736-0266(02)00066-9

10. Hou CJ, Liu JL, Li X, Bi LJ. Insulin promotes bone formation in augmented maxillary sinus in diabetic rabbits. Int J Oral Maxillofac Surg. 2012;41(3):400-7. https://doi.org/10.1016/j.jom.2011.10.004 PMid:22099315

11. Sellmeyer DE, Civitelli R, Hofbauer LC, Khosla S, Lecka-Czernik B, Schwartz AV. Skeletal Metabolism, Fracture Risk, and Fracture Outcomes in Type 1 and Type 2 Diabetes. Diabetes. 2016;65(7):1757-66. https://doi.org/10.2337/db16-0063 PMid:27329951 PMCid:PMC4915586

12. Jehle PM, Jehle DR, Mohan S, Bohm BO. Serum levels of insulin-like growth factor system components and relationship to bone metabolism in Type 1 and Type 2 diabetes mellitus patients. J Endocrinol. 1998;159(2):297306. https://doi.org/10.1677/joe.0.1590297 PMid:9795371

13. Gerstenfeld LC, Wronski TJ, Hollinger JO, Einhorn TA. Application of histomorphometric methods to the study of bone repair. J Bone Miner Res. 2005;20(10):1715-22. https://doi.org/10.1359/JBMR.050702 PMid:16160729

14. Loder RT. The influence of diabetes mellitus on the healing of closed fractures. Clin Orthop Relat Res. 1988(232):210-6. https://doi.org/10.1097/00003086-198807000-00028

15. Chaudhary SB, Liporace FA, Gandhi A, Donley BG, Pinzur MS, Lin SS. Complications of ankle fracture in patients with diabetes. J Am Acad Orthop Surg. 2008;16(3):159-70. https://doi.org/10.5435/00124635-200803000-00007 PMid: 18316714

16. Gooch $\mathrm{HL}$, Hale JE, Fujioka $\mathrm{H}$, Balian G, Hurwitz SR. Alterations of cartilage and collagen expression during fracture healing in experimental diabetes. Connect Tissue Res. 2000;41(2):81-91. https://doi.org/10.3109/03008200009067660 PMid:10992154

17. Gandhi A, Beam HA, O'Connor JP, Parsons JR, Lin SS. The effects of local insulin delivery on diabetic fracture healing. Bone. 2005;37(4):482-90. https://doi.org/10.1016/j.bone.2005.04.039 PMid:16027060

18. Caley MP, Martins VL, O'Toole EA. Metalloproteinases and Wound Healing. Adv Wound Care (New Rochelle). 2015;4(4):225-34. https://doi.org/10.1089/wound.2014.0581 PMid:25945285 PMCid:PMC4397992

19. Chockalingam PS, Zeng W, Morris EA, Flannery CR. Release of hyaluronan and hyaladherins (aggrecan G1 domain and link proteins) from articular cartilage exposed to ADAMTS-4 (aggrecanase 1) or ADAMTS-5 (aggrecanase 2). Arthritis Rheum. 2004;50(9):2839-48. https://doi.org/10.1002/art.20496 PMid:15457452

20. Yaykasli KO, Oohashi T, Hirohata S, Hatipoglu OF, Inagawa K, Demircan K, et al. ADAMTS9 activation by interleukin 1 beta via NFATc1 in OUMS-27 chondrosarcoma cells and in human chondrocytes. Mol Cell Biochem. 2009;323(1-2):69-79. https://doi.org/10.1007/s11010-008-9965-4 PMid:19052845 
21. Kumagishi K, Nishida K, Yamaai T, Momota R, Miyaki S, Hirohata S, et al. A disintegrin and metalloproteinase with thrombospondin motifs 9 (ADAMTS9) expression by chondrocytes during endochondral ossification. Arch Histol Cytol. 2009;72(3):175-85. https://doi.org/10.1679/aohc.72.175 PMid:20513980

22. Aiken A, Khokha R. Unraveling metalloproteinase function in skeletal biology and disease using genetically altered mice. Biochim Biophys Acta. 2010;1803(1):121-32. https://doi.org/10.1016/j.bbamcr.2009.07.002 PMid:19616584

23. Uysal S, Unal ZN, Erdogan S, Akyol S, Ramazan Yigitoglu M, Hirohata S, et al. Augmentation of ADAMTS9 gene expression by IL-1 beta is reversed by NFkappaB and MAPK inhibitors, but not PI3 kinase inhibitors. Cell Biochem Funct. 2013;31(7):539-44. https://doi.org/10.1002/cbf.2932 PMid:23175174

24. Gerstenfeld LC, Thiede M, Seibert K, Mielke C, Phippard D, Svagr B, et al. Differential inhibition of fracture healing by non-selective and cyclooxygenase-2 selective non-steroidal anti-inflammatory drugs. J Orthop Res. 2003;21(4):670-5. https://doi.org/10.1016/S0736-0266(03)00003-2

25. Follak N, Kloting L, Wolf $E$, Merk $\mathrm{H}$. Delayed remodeling in the early period of fracture healing in spontaneously diabetic BB/OK rats depending on the diabetic metabolic state. Histol Histopathol. 2004;19(2):473-86.

26. White $C B$, Turner NS, Lee GC, Haidukewych GJ. Open ankle fractures in patients with diabetes mellitus. Clin Orthop Relat Res. 2003(414):37-44. https://doi.org/10.1097/01.blo.0000084402.53464.90 PMid:12966274

27. Kayal RA, Tsatsas D, Bauer MA, Allen B, Al-Sebaei MO, Kakar S, et al. Diminished bone formation during diabetic fracture healing is related to the premature resorption of cartilage associated with increased osteoclast activity. J Bone Miner Res. 2007;22(4):560-8. https://doi.org/10.1359/jbmr.070115 PMid:17243865 PMCid:PMC3109431

28. Otsu K, Geary ES, Stevens RL. Aberrant regulation of the metabolism of the insulin receptor in Swarm rat chondrosarcoma chondrocytes. Biochem J. 1988;254(1):203-9. https://doi.org/10.1042/bj2540203 PMid:3052429 PMCid:PMC1135057

29. Stevens RL, Hascall VC. Characterization of proteoglycans synthesized by rat chondrosarcoma chondrocytes treated with multiplication-stimulating activity and insulin. J Biol Chem. 1981;256(4):2053-8.

30. Bembenek ME, Willis DH, Jr., Liberti JP. The effect of insulin on collagen production in isolated chondrosarcoma chondrocytes. Biochem Biophys Res Commun. 1982;106(2):338-45. https://doi.org/10.1016/0006291X(82)91115-9

31. Mason RM, Kimura JH, Hascall VC. Biosynthesis of hyaluronic acid in cultures of chondrocytes from the Swarm rat chondrosarcoma. J Biol Chem. 1982;257(5):2236-45.

32. Stevens RL, Nissley SP, Kimura JH, Rechler MM, Caplan Al, Hascall VC. Effects of insulin and multiplicationstimulating activity on proteoglycan biosynthesis in chondrocytes from the Swarm rat chondrosarcoma. J Biol Chem. 1981;256(4):2045-52.

33. Salomon DS, Paglia LM, Verbruggen L. Hormone-dependent growth of a rat chondrosarcoma in vivo. Cancer Res. 1979;39(11):4387-95.

34. Kevorkian L, Young DA, Darrah C, Donell ST, Shepstone L, Porter S, et al. Expression profiling of metalloproteinases and their inhibitors in cartilage. Arthritis Rheum. 2004;50(1):131-41. https://doi.org/10.1002/art.11433 PMid:14730609

35. Kayal RA, Alblowi J, McKenzie E, Krothapalli N, Silkman L, Gerstenfeld L, et al. Diabetes causes the accelerated loss of cartilage during fracture repair which is reversed by insulin treatment. Bone. 2009;44(2):357-63. https://doi.org/10.1016/j.bone.2008.10.042 PMid:19010456 PMCid:PMC2700945

36. Cawston TE, Wilson AJ. Understanding the role of tissue degrading enzymes and their inhibitors in development and disease. Best Pract Res Clin Rheumatol. 2006;20(5):983-1002. https://doi.org/10.1016/j.berh.2006.06.007 PMid:16980219

37. Stickens D, Behonick DJ, Ortega N, Heyer B, Hartenstein B, Yu Y, et al. Altered endochondral bone development in matrix metalloproteinase 13-deficient mice. Development. 2004;131(23):5883-95. https://doi.org/10.1242/dev.01461 PMid:15539485 PMCid:PMC2771178

38. Kennedy AM, Inada M, Krane SM, Christie PT, Harding B, Lopez-Otin C, et al. MMP13 mutation causes spondyloepimetaphyseal dysplasia, Missouri type (SEMD(MO). J Clin Invest. 2005;115(10):2832-42. https://doi.org/10.1172/JCI22900 PMid:16167086 PMCid:PMC1201660

39. Little CB, Mittaz L, Belluoccio D, Rogerson FM, Campbell IK, Meeker CT, et al. ADAMTS-1-knockout mice do not exhibit abnormalities in aggrecan turnover in vitro or in vivo. Arthritis Rheum. 2005;52(5):1461-72. https://doi.org/10.1002/art.21022 PMid:15880348 
40. Stanton $\mathrm{H}$, Rogerson FM, East CJ, Golub SB, Lawlor KE, Meeker CT, et al. ADAMTS5 is the major aggrecanase in mouse cartilage in vivo and in vitro. Nature. 2005;434(7033):648-52. https://doi.org/10.1038/nature03417 PMid:15800625

41. Kuno K, Kanada N, Nakashima E, Fujiki F, Ichimura F, Matsushima K. Molecular cloning of a gene encoding a new type of metalloproteinase-disintegrin family protein with thrombospondin motifs as an inflammation associated gene. J Biol Chem. 1997;272(1):556-62. https://doi.org/10.1074/jbc.272.1.556 PMid:8995297

42. Sandy JD, Westling J, Kenagy RD, Iruela-Arispe ML, Verscharen C, Rodriguez-Mazaneque JC, et al. Versican V1 proteolysis in human aorta in vivo occurs at the Glu441-Ala442 bond, a site that is cleaved by recombinant ADAMTS-1 and ADAMTS-4. J Biol Chem. 2001;276(16):13372-8. https://doi.org/10.1074/jbc.M009737200 PMid:11278559

43. Vazquez F, Hastings G, Ortega MA, Lane TF, Oikemus $S$, Lombardo $M$, et al. METH-1, a human ortholog of ADAMTS-1, and METH-2 are members of a new family of proteins with angio-inhibitory activity. J Biol Chem. 1999;274(33):23349-57. https://doi.org/10.1074/jbc.274.33.23349 PMid:10438512

44. Twining SS. Regulation of proteolytic activity in tissues. Crit Rev Biochem Mol Biol. 1994;29(5):315-83. https://doi.org/10.3109/10409239409083484 PMid:7828434

45. Demircan K, Comertoglu I, Akyol S, Yigitoglu BN, Sarikaya E. A new biological marker candidate in female reproductive system diseases: Matrix metalloproteinase with thrombospondin motifs (ADAMTS). J Turk Ger $\begin{array}{llll}\text { Gynecol } \quad \text { Assoc. 2014;15(4):250-5. https://doi.org/10.5152/jtgga.2014.14206 PMid:25584036 } & \end{array}$ PMCid:PMC4285216

46. Akyol S, Ugurcu V, Cakmak O, Altuntas A, Yukselten Y, Akyol O, et al. Evidence for the control of aggrecanases by insulin and glucose in Alzheimer's disease. Bull Clin Psychopharmacol. 2014;24(1):323-32. https://doi.org/10.5455/bcp.20140905124459

47. Hardingham TE, Fosang AJ. Proteoglycans: many forms and many functions. FASEB J. 1992;6(3):861-70. https://doi.org/10.1096/fasebj.6.3.1740236

48. Zhang $E$, Yan $X$, Zhang $M$, Chang $X$, Bai Z, He Y, et al. Aggrecanases in the human synovial fluid at different stages of osteoarthritis. Clin Rheumatol. 2013;32(6):797-803. https://doi.org/10.1007/s10067-013-2171-0 PMid:23370724

49. Zeng W, Corcoran C, Collins-Racie LA, Lavallie ER, Morris EA, Flannery CR. Glycosaminoglycan-binding properties and aggrecanase activities of truncated ADAMTSs: comparative analyses with ADAMTS-5, $-9,-16$ and -18 . Biochim Biophys Acta. 2006;1760(3):517-24. https://doi.org/10.1016/j.bbagen.2006.01.013 PMid:16507336

50. Yamanishi Y, Boyle DL, Clark M, Maki RA, Tortorella MD, Arner EC, et al. Expression and regulation of aggrecanase in arthritis: the role of TGF-beta. J Immunol. 2002;168(3):1405-12. https://doi.org/10.4049/jimmunol.168.3.1405 PMid:11801682

51. Malfait AM, Liu RQ, Ijiri K, Komiya S, Tortorella MD. Inhibition of ADAM-TS4 and ADAM-TS5 prevents aggrecan degradation in osteoarthritic cartilage. J Biol Chem. 2002;277(25):22201-8. https://doi.org/10.1074/jbc.M200431200 PMid:11956193

52. Tortorella MD, Pratta M, Liu RQ, Austin J, Ross OH, Abbaszade I, et al. Sites of aggrecan cleavage by recombinant human aggrecanase-1 (ADAMTS-4). J Biol Chem. 2000;275(24):18566-73. https://doi.org/10.1074/jbc.M909383199 PMid:10751421

53. Tortorella MD, Liu RQ, Burn T, Newton RC, Arner E. Characterization of human aggrecanase 2 (ADAM-TS5): substrate specificity studies and comparison with aggrecanase 1 (ADAM-TS4). Matrix Biol. 2002;21(6):499-511. https://doi.org/10.1016/S0945-053X(02)00069-0

$\diamond \diamond \diamond \diamond \diamond \diamond \diamond$

http://www.ejgm.co.uk 